\title{
Morphine-Induced Dependence and Sensitization Are Altered in Mice Deficient in AMPA-Type Glutamate Receptor-A Subunits
}

\author{
Olga Y. Vekovischeva, ${ }^{1,2}$ Daniel Zamanillo, ${ }^{3}$ Oxana Echenko, ${ }^{1}$ Timo Seppälä, ${ }^{4}$ Mikko Uusi-Oukari, ${ }^{1}$ \\ Aapo Honkanen,, ${ }^{1}$ Peter H. Seeburg, ${ }^{3}$ Rolf Sprengel, ${ }^{3}$ and Esa R. Korpi ${ }^{1}$ \\ ${ }^{1}$ Department of Pharmacology and Clinical Pharmacology, University of Turku, FIN-20520 Turku, Finland, 2International \\ Graduate School in Neurosciences, University of Tampere Medical School, FIN-33101 Tampere, Finland, ${ }^{3}$ Department of \\ Molecular Neurobiology, Max-Planck Institute for Medical Research, D-69120 Heidelberg, Germany, and ${ }^{2}$ Laboratory of \\ Substance Abuse, National Public Health Institute, FIN-00300 Helsinki, Finland
}

\begin{abstract}
AMPA-type glutamate receptors have been suggested to be involved in the neurobiological mechanisms of drug addiction. We have made use of two mouse lines, which both have modulated AMPA receptor responses. The first line is entirely deficient in glutamate receptor-A (GluR-A) subunits (A-Iknock-out line) and, in the second one, the Q582 residue of GluR-A subunits is replaced by an arginine residue (R/R mutants), which reduces the calcium permeability and channel conductance of the receptors containing this mutated subunit. Mice of both lines are healthy, but they show slightly increased locomotor activity. Acute morphine administration enhanced locomotor activity of the GluR-A-/- and GluR-A(R/R) mice, at least as much as that of their wild-type littermates. Only in the GluR-A-/- mice did we observe reduced tolerance development in tail-flick antinociception and less severe naloxoneprecipitated withdrawal symptoms after treatment with increasing morphine doses, without differences in plasma and brain
\end{abstract}

Addiction to chemical substances develops in a set of molecular events in the brain. First, all addictive substances act on primary molecular targets, some of them being already well characterized (Rodriguez de Fonseca and Navarro, 1998; Self, 1998; Self and Nestler, 1998; Merlo Pich et al., 1999). Opiates require specific G-protein-coupled receptors for their efficacy, e.g., morphine is acting primarily on $\mu$-opioid receptors (Matthes et al., 1996). Second, the mesolimbic dopaminergic system has been suggested to be a pathway, which is activated by most addictive drugs (Bardo, 1998; Koob et al., 1998; Everitt et al., 1999; Leshner and Koob, 1999). Third, repeated usage of addictive drugs, producing, for example, behavioral sensitization, leads to multiple adaptive neuronal responses, some of these adaptations including permanent changes in synaptic structures (Robinson and Kolb, 1997,

\footnotetext{
Received Dec. 13, 2000; revised March 15, 2001; accepted March 23, 2001.

This work was supported in part by the Academy of Finland, the National Technology Agency Tekes, and the Sigrid Juselius Foundation (E.R.K.), the Finnish Cultural Foundation (A.H.), European Union Framework Program Grant QLG3CT-1999-01022 (P.H.S.), and Deutsche Forschungsgemeinschaft Sonderforschungsbereich Grant 317 and the Volkswagen-Stiftung (R.S.). D.Z. was the recipient of a postdoctoral fellowship from Human Frontier Science Program. We thank F. Zimmermann for technical assistance, Hua Gu for plasmid pMC-Cre, and Andras Nagy for providing embryonic stem cells R1 and plasmid ploxPneo1. Cre was used under a noncommercial research license agreement between DuPont Pharmaceutical Company and the Max-Planck-Society.

Correspondence should be addressed to Dr. Esa R. Korpi, Department of Pharmacology and Clinical Pharmacology, University of Turku, FIN-20520 Turku, Finland. E-mail: esa.korpi@utu.fi.

Copyright (C) 2001 Society for Neuroscience $0270-6474 / 01 / 214451-09 \$ 15.00 / 0$
}

morphine levels when compared with wild type. Repeated daily morphine administration sensitized the locomotor activity responses in the GluR-A-/- and GluR-A(R/R) mice only when given in the measuring cages, whereas the wild-type mice showed slightly increased responses also when the repeated treatment was given in their home cages. Normal or even enhanced context-dependent sensitization was observed also with repeated amphetamine administration in the GluR-A subunit-deficient mice. The results indicate that AMPA receptors are involved in the acute and chronic effects of morphine, including context-independent sensitization, and that the GluR-A subunit itself is important for morphine tolerance and dependence.

Key words: neurobiology of addiction; glutamate receptors; AMPA receptors; transgenic mouse lines; morphine; amphetamine

1999). The adaptive responses require altered gene expression (Koob et al., 1998; Berke and Hyman, 2000; Nestler, 2000). Some of these adaptive processes may thus serve as acquired molecular twitches, making a subject prone to develop dependence to chemical substances on repeated usage.

One interesting candidate protein that has been shown to be upregulated in the brains of animals addicted to morphine and other drugs of abuse is a subunit of AMPA-type glutamate receptors, namely GluR-A subunit (Fitzgerald et al., 1996). Druginduced changes in GluR-A subunit in various brain regions have been observed at both protein and mRNA levels (Lu et al., 1997; Churchill et al., 1999; Lu and Wolf, 1999; Jang et al., 2000), indicating that GluR-A subunit-containing AMPA receptors might be involved in the activation of brain pathways associated with a drug-sensitized state. Importantly, Carlezon et al. (1997) have produced evidence that viral-mediated upregulation of GluR-A subunit levels in the ventral tegmental area, the origin of mesolimbic dopaminergic pathway, is enough to mimic the morphine-sensitized state in rats. This suggests a causal relationship between the effects of drugs of abuse and behavioral effects via GluR-A subunit-containing AMPA receptors (Carlezon et al., 1997).

To provide additional genetic evidence of the involvement of AMPA receptors in drug addiction, we investigated mice of two lines, both of which have altered AMPA receptor responses. Both lines were generated by gene-targeted modification of the mouse 

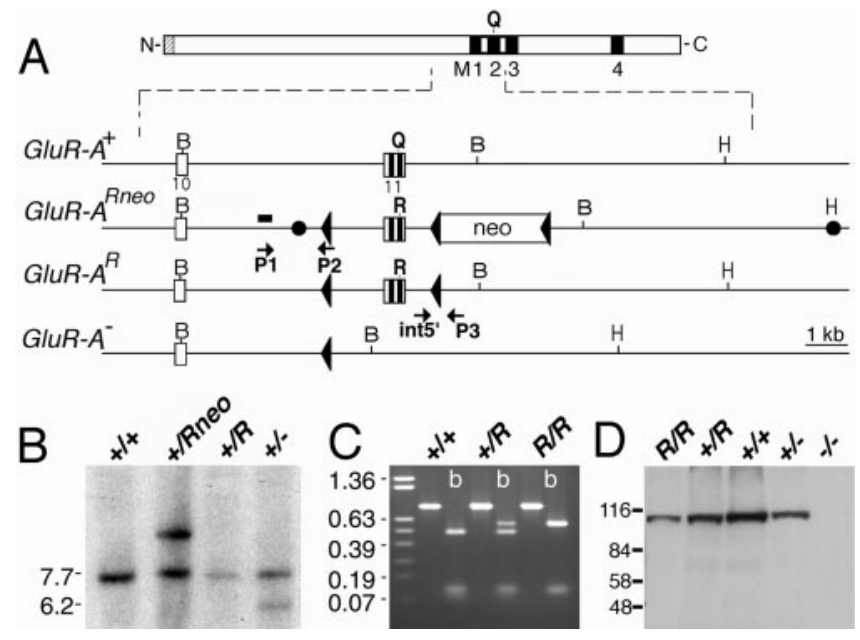

Figure 1. Generation of GluR-A(R/R) mice. $A$, Representation of the GluR-A subunit and of GluR-A+, GluR-A(R $\left.{ }^{\text {neo }}\right)$, GluR-A(R), and GluR-A gene fragments. Black boxes represent putative membrane segments M1 to M4. For the gene segment, open boxes represent exonic sequences and the PGK-NEO gene (neo). loxP sites are shown by triangles. Two filled circles in GluR- $A^{\text {neo }}$ indicate $5^{\prime}$ and $3^{\prime}$ ends of the targeting construct. Positions of BamHI $(B)$ and HindIII $(H)$ restriction enzyme recognition sites are given. The $260 \mathrm{bp}$ genomic $S a c$ I fragment used as probe for the genomic Southern blot is depicted as a black bar. P1 and P2 arrows represent primers used for screening of the targeted allele. ES cell clones were confirmed by using the primer set int $5^{\prime}$ and P3. B, Southern blot analysis of BamHI-digested genomic ES cell DNA derived from ES cell colonies, which were injected into blastocysts. The GluR-A+ and GluR-A(R) alleles are visualized as $7.2 \mathrm{~kb}$, the targeted GluR-A(R $\left.{ }^{\text {neo }}\right)$ as $9.2 \mathrm{~kb}$, and the GluR-A - allele as $5.7 \mathrm{~kb}$ fragments, respectively. Positions of the molecular weight marker in kilobase pairs are given on the left. $C$, RT-PCR on total brain mRNA derived from mice with genotypes as indicated using primers exon9 and exon 12 EcoRI to amplify a $800 \mathrm{bp}$ fragment. By $B b v \mathrm{I}$ digestion (b), GluR-A and GluR(R) mRNA derived fragments of 471,120,106, and $103 \mathrm{bp}$ and of 577, 120, and $103 \mathrm{bp}$ can be visualized by ethidium bromide staining in a $1 \%$ agarose gel. Size markers in kilobases are given on the left. $D$, Immunoblot analysis demonstrating the expression of the GluR-A(R) subunit in brains of GluR-A(R/R) mice. Membrane proteins of forebrain from genotypes as indicated were separated in $8 \%$ SDS-polyacrylamide gel and visualized by anti-GluR-A antibody. The molecular weight marker in kilodaltons is given on the left.

GRIA-1 gene. In mice of the GluR-A-/- line, the GluR-A subunit is not expressed at all, whereas mice of GluR-A(R/R) line express the mutated version of GluR-A with glutamine (Q582) replaced by an arginine $(\mathrm{R})$. In principal neurons of the hippocampus, most AMPA receptor channels are now formed by subunits containing R582, and those channels are known to have very low single-channel conductance (Burnashev et al., 1992; Swanson et al., 1997). In interneurons, which lack the GluR-B subunits, we expect no reduction of AMPA currents but a shift to less $\mathrm{Ca}^{2+}$-permeable channels. We found that these novel mouse models do show responses to morphine and D-amphetamine, although in a different manner from their wild-type littermate controls, which clarifies the role of AMPA receptors in the effects of and in the neuronal adaptation to drugs of abuse.

\section{MATERIALS AND METHODS}

Generation of GluR-A-/- and GluR-A(R/R) mice. GluR-A-/- mice were generated as described previously (Zamanillo et al., 1999). GluR$\mathrm{A}(\mathrm{R} / \mathrm{R})$ mice were created by targeted GluR-A mutagenesis in $\mathrm{R} 1$ mouse embryonic stem (ES) cells (Nagy et al., 1993). The targeting vector pFCII-R contained $10.7 \mathrm{~kb}$ of the murine GluR-A gene (GRIA1) with parts of introns 10 and 11 and mutated exon 11, numbered according to the GluR-B gene (Kohler et al., 1994) (Fig. 1). The Q582 to R582 mutation (CAG to CGG) was introduced by PCR in an exon 11containing plasmid. An NsiI-BglII wild-type fragment from the construct was substituted by an Nsi I-BglII segment encoding the CAG to CGG mutation. The neo selection marker ploxPneo3 (Single et al., 2000) was inserted into an EcoNI site, 700 bp into intron 11. In addition, in 225 nucleotides upstream of exon 10, a 28 bp PflMI fragment was substituted by a 34 bp loxP site. ES cells (R1) were electroporated with the targeting vector and linearized at the unique HindIII site in the polylinker, and five positive clones were identified by PCR with primers P1 and P2 (Zamanillo et al., 1999) and confirmed by Southern blotting with a 162 bp SacI fragment of intron 10 as $5^{\prime}$ outside probe. One positive ES cell clone was transfected with a Cre recombinase expression vector (pMC-Cre) (Gu et al., 1993), and clones with two loxP sites and without neo selection marker in the modified GluR-A allele were identified by PCR with primer pair int5' (GGT AAT ATG CTG TCA AGA TGC) and loxP0 (ACT CGA GGG ACC TAA TAA CTT CG). The positive clones were confirmed by using a second primer set int5' and P3 (Zamanillo et al., 1999). This primer pair identified the mutated and wild-type allele (a 60 nucleotide shorter product) by PCR. Cre-mediated deletion of the neo gene was confirmed by Southern blotting using the $162 \mathrm{bp} \mathrm{SacI}$ fragment described above. Subclone 57.4 was injected into C57BL/6 blastocysts, chimeric animals were backcrossed to $\mathrm{C} 57 \mathrm{BL} / 6$, and intercrosses produced $25 \%$ GluR-A(R/R) mice.

Homozygous GluR-A(R/R) showed normal expression levels of the mutated GluR-A(R) subunit in the forebrain, whereas the GluR-A-/animals lacked the subunit protein (Fig. 1). However, similar to the GluR-A-/- animals (Zamanillo et al., 1999), their AMPA receptormediated currents in somata of CA1 pyramidal cells were at least 10 -fold reduced (T. Borchardt and R. Sprengel, unpublished observations).

The mouse lines were constructed and backcrossed three times with C57BL/6 mice in Germany, and breeding pairs were transferred to Turku, Finland. The experimental animals were produced by heterozygous mating from the $\mathrm{F}_{5-7}$ generations. The genotype of the animals was checked out before behavioral experiments by PCR analysis of tail-tip DNA (Brusa et al., 1995). Primer pair MH60 (CAC TCA CAG CAA TGA AGC AGG AC) and P3 amplified a 215 bp fragment from the wild-type allele and a $250 \mathrm{bp}$ fragment from the GluR-A(R) allele. Primer combination 1005 (AAT GCC TAG TAC TAT AGT GCA CG) and $\mathrm{P} 3$ was used to get a $1500 \mathrm{bp}$ fragment from the wild-type allele and a $275 \mathrm{bp}$ fragment from the GluR-A- allele.

Animal care was in compliance with the institutional guidelines at the animal facility of the Center for Molecular Biology (Heidelberg, Germany). Transgenic manipulations were performed according to a license (37-9185.81/35/97) of the Regierungspräsidium (Karlsruhe, Germany).

In Turku, adult mice were maintained in individual polypropylene cages $(20 \times 10 \times 15 \mathrm{~cm})$ in a facility artificially illuminated from 7:00 A.M. to 7:00 P.M. with air conditioning $\left(21 \pm 1{ }^{\circ} \mathrm{C}\right)$ and relative humidity of $50-60 \%$. Tap water and rodent pellets (Special Diet Service; Witham, Essex, UK) were available ad libitum. All experimental protocols were approved by the Institutional Animal Care and Use Committee of the University of Turku. In most experiments, both male (weight of $28-38 \mathrm{gm}$ ) and female (weight of 20-28 gm) animals were used from all lines because, in preliminary experiments, we failed to detect any gender differences in locomotor activity or nociception (see Results).

Gene expression analysis. Reverse transcription (RT)-PCR amplification of GluR-A mRNA sequences was performed with primers exon9 (GTC CAG AAT AGA ACC TAC ATC G) and exon12EcoRI (GTG AAT TCT GCT TCC AAT GTG CCA TAA GC) to amplify a $800 \mathrm{bp}$ DNA fragment. The origin of PCR fragments was determined by $B b v \mathrm{I}$ restriction enzyme digestion, which produced 471, 120, 106, and $103 \mathrm{bp}$ fragments for wild type, and 577, 120, and 103 bp fragments for mRNA derived from the mutated GluR-A(R) allele. For quantitative analysis, pictures of ethidium bromide-stained gels were digitized by scanning (Gt 9600; Epson, Long Beach, CA), and the densiometric analysis was performed by Image Gauge version 3.0 (Fujifilm, Tokyo, Japan). It revealed $42 \%$ GluR-A(R) mutant mRNA expression relative to total GluR-A mRNA, instead of the expected $50 \%$. The slightly reduced expression level of the mutant allele is probably attributable to the insertion of loxP sites in intron 10 and 11.

Immunoblotting. Isolated hippocampi were homogenized in $0.32 \mathrm{M}$ sucrose and $5 \mathrm{~mm}$ HEPES, pH 7.4, containing a cocktail of protease inhibitors (Complete; Boehringer Mannheim, Mannheim, Germany), and centrifuged for $15 \mathrm{~min}$ at $3000 \times \mathrm{g}$. The supernatant was subsequently centrif uged for $30 \mathrm{~min}$ at $10,000 \times g$. The pellet was resuspended in $1 \% \mathrm{SDS}$, and the amount of total protein was determined (Pierce, 
Rockford, IL). For each sample, $20 \mu \mathrm{g}$ of total membrane protein was resolved on an $8 \%$ SDS-polyacrylamide gel, and the separated proteins were transferred to nitrocellulose membranes. Blots were probed with anti-GluR-A polyclonal antibody at $1 \mu \mathrm{g} / \mathrm{ml}$ (Chemicon, Temecula, CA), followed by horseradish peroxidase-linked anti-rabbit secondary antibodies. The enhanced chemiluminescence method (ECL; Amersham Pharmacia Biotech, Buckingamshire, UK) was used to detect GluR-A. To verify that equal amounts of protein were loaded in each lane, the lower part of the SDS-polyacrylamide gel was cut off before semidry electroblotting and Coomassie blue-stained, and then the image was densitometrically analyzed (NIH Image version 1.56; data not shown).

Determination of locomotor activity. The horizontal locomotor activity (ambulation) of the mice was measured in animals placed in transparent $25 \times 42 \times 19 \mathrm{~cm}$ plastic cages equipped with computer-controlled photocells automatically monitoring the movements (Photobeam Activity System; San Diego Instruments, San Diego, CA). The cages were arranged on the shelves and illuminated by artificial lights with an average intensity of 290 lux. Locomotor activity was recorded for $5 \mathrm{~min}$ periods (time course) and then calculated for the total test time (total locomotor activity, usually for $120 \mathrm{~min}$ ).

Determination of tail-flick latencies. The mouse was lightly restrained, and its tail ( $2 \mathrm{~cm}$ from the base) was exposed to a focused infrared heat beam (intensity set to 50; Ugo Basile, Comerio, Italy). The animal could voluntarily terminate the noxious stimulation by flicking its tail, and the latency to this reaction was then recorded. An animal that failed to respond in $10 \mathrm{sec}$ (cutoff time) was removed from the apparatus and assigned the latency of $10 \mathrm{sec}$. On the test day (the first and ninth day of chronic morphine treatment), baseline tail-flick latencies were first measured twice for each animal. Saline $(10 \mathrm{ml} / \mathrm{kg}$, s.c.) or morphine $(5$ $\mathrm{mg} / \mathrm{kg}$ ) was injected after the baseline measurements, and the mice were retested 30 and $60 \mathrm{~min}$ after the injections in two trials for tail-flick latencies. Tail-flick latencies were converted to percentage of the maximal possible effect (MPE). The individual antinociceptive values (\%MPE) were calculated according to the formula: $\left[\left(T_{\exp }-T_{\mathrm{BL}}\right) \times\right.$ $100] /\left(10-T_{\mathrm{BL}}\right)$, where $T_{\exp }$ is the tail-flick latency and $T_{\mathrm{BL}}$ the baseline latency.

Determination of withdrawal signs. Naloxone-precipitated opioid withdrawal symptoms were determined using a cylinder test. The observations were performed in six identical glass cylinders (diameter of $20 \mathrm{~cm}$; height of $40 \mathrm{~cm}$ ) by video recording. The behavioral parameters (number of jumps, digging, stretches, "wet dog"-like shakes, forepaw tremor, forepaw treading, head twitch, writhing and the presence of ptosis, piloerection, and diarrhea) were monitored from the video recordings for 15-25 min after naloxone injection. The body weights were measured before the naloxone injection, and 20 and $60 \mathrm{~min}$ after it. One score point was given of each parameter, and the total number of score points was calculated for each mouse (Malin et al., 1992). Withdrawal-induced changes in the total scores of the morphine-treated mice were compared with naloxone-induced behavioral and somatic symptoms in salinetreated control mice.

Morphine treatment regimens. Acute sensitivity of each mouse line to morphine-induced locomotion was assessed in locomotor cages using animals that had been habituated to the measuring cage for $2 \mathrm{hr} / \mathrm{d}$ on 3 preceding days. Animals were injected subcutaneously with saline (10 $\mathrm{ml} / \mathrm{kg}$ ) and 3,10 , and $30 \mathrm{mg} / \mathrm{kg}$ morphine hydrochloride (European Pharmacopoeia), and the locomotor activity was recorded immediately for $2 \mathrm{hr}$. A $1 \mathrm{~d}$ interval was kept between the increasing doses.

Sensitization to repeated morphine was assessed in the following manner to find out the dependency on the environmental context of the treatment. First, all experimentally naïve animals were adapted to locomotor boxes for $2 \mathrm{hr} / \mathrm{d}$ on 3 preceding days. Then, all animals received 3 $\mathrm{mg} / \mathrm{kg}$ subcutaneous morphine and, immediately after the injection, their locomotor activities were monitored for $2 \mathrm{hr}$ (test 1). This locomotor activity reflected the initial sensitivity to a low morphine dose, which afterward was compared with the activity induced by the same morphine dose after repeated morphine treatment. Repeated morphine treatment was performed using the following regimen. One day after test 1 , the animals were randomly divided into paired (P), unpaired (UP), and control (C) groups. Each group received two injections per day with 10 hr intervals. For the P group, the first injection between 9:00 and 10:00 A.M. (10 mg/kg morphine) was given in locomotor cages, in which the mice stayed for $2 \mathrm{hr}$ after the injection, and after the second (saline) injection these animals remained in their home cages. The UP group received the injections on the opposite schedule. Morphine was given in home cage, whereas saline injection was followed by $2 \mathrm{hr}$ in the locomo- tor cages. The $\mathrm{C}$ group received saline injections in both home cages and locomotor cages. Finally, retests of $3 \mathrm{mg} / \mathrm{kg}$ morphine-induced activity were performed at $24 \mathrm{hr}$ (test 2) and $5 \mathrm{~d}$ (test 3) after the last injection of day 6 as described for test 1 .

Development of tolerance and dependence to morphine was assessed during a 9 d regimen (Belozertseva et al., 1996). On day 1, the mice were randomly divided into two treatment groups (morphine and saline groups). Before the drug treatment, all mice were tested with a tail-flick test for the sensitivity to analgesic action of morphine $(5 \mathrm{mg} / \mathrm{kg})$. Ten hours after this test, the morphine group received morphine $(10 \mathrm{mg} / \mathrm{kg}$, s.c.), and the saline group received the equivalent volume of saline (10 $\mathrm{ml} / \mathrm{kg}$ ). During the next $7 \mathrm{~d}$, the morphine group received twice daily at 9:00 A.M. and 6:00 P.M. increasing subcutaneous doses of morphine according to the following schedule (in $\mathrm{mg} / \mathrm{kg}$ ): day 2, 20; day 3, 30; day 4, 40; day 5, 50; day 6, 60; day 7, 70; and day 8, 80. The control group received saline at the same schedule. Body weights were determined every second day. The first injection of morphine on day 9 was $5 \mathrm{mg} / \mathrm{kg}$, and the tail-flick test was performed after 30 and $60 \mathrm{~min}$ to assess the development of tolerance. Immediately after the test, the morphine group received additionally $95 \mathrm{mg} / \mathrm{kg}$ morphine to reach the cumulative dose of $100 \mathrm{mg} / \mathrm{kg}$. The second injection on day 9 was omitted. On day 10 (24 hr after the last dose of morphine), all groups were treated with naloxone hydrochloride $(0.4 \mathrm{mg} / \mathrm{kg}$, s.c.; Research Biochemicals, Natick, MA) to determine the severity of morphine withdrawal symptoms as described above.

The development of morphine dependence was repeated with GluR$\mathrm{A}-/-$ mutants and their littermates by using a slightly modified procedure (Matthes et al., 1996). During $6 \mathrm{~d}$, the morphine groups of both lines received subcutaneous doses of morphine twice daily as follows (in $\mathrm{mg} / \mathrm{kg}$ ): day 1, 20; day 2, 40; day 3, 60; day 4, 80; day 5, 100; and day 6, only a morning dose of morphine $(100 \mathrm{mg} / \mathrm{kg})$ was given. Control groups were treated with saline under the same conditions. The withdrawal symptoms were precipitated to all mice $2 \mathrm{hr}$ after the last morphine or saline injection by naloxone $(1 \mathrm{mg} / \mathrm{kg}$, s.c.) and evaluated for a period of $25 \mathrm{~min}$ as described above.

Amphetamine and dizocilpine administrations. On 3 consecutive days, the mice were adapted to locomotor boxes for $2 \mathrm{hr} / \mathrm{d}$. For drug treatment, the mice of each line were divided into two groups, which received subcutaneously either saline $(10 \mathrm{ml} / \mathrm{kg})$ or D-amphetamine sulfate $(2$ $\mathrm{mg} / \mathrm{kg}$; Sigma, St. Louis, MO) daily. After the injection, half of the animals were immediately tested in familiar locomotor boxes (paired groups), whereas the others remained as unpaired controls being transferred to their home cages after the injection. The treatment was repeated on the following $4 \mathrm{~d}$. The test for sensitization to amphetamineinduced locomotor activity was performed $5 \mathrm{~d}$ after the last injection. The amphetamine-treated groups received amphetamine $(0.5 \mathrm{mg} / \mathrm{kg})$. The saline groups of each line were divided into two groups that were treated with either saline or amphetamine $(0.5 \mathrm{mg} / \mathrm{kg})$. GluR-A(R/R) mice were studied only in the paired protocol.

Adaptation of the mice to locomotor boxes was performed for $1 \mathrm{hr}$ on the day before the experiment began and before each drug session. Acute effect of (+)-5-methyl-10,11-dihydro-5H-dibenzo [a,d] cyclohepten-5,10imine maleate (dizocilpine; MK-801) (Sigma) on locomotor activity of knock-out mice and their littermates was tested by Latin square design using the following intraperitoneal doses: $0.1,0.3,0.5$, and $1.0 \mathrm{mg} / \mathrm{kg}$.

Determination of morphine concentrations in plasma and brain. Male GluR-A-/- mice and their controls were injected with $10 \mathrm{mg} / \mathrm{kg}$ morphine. The mice ( $n=7-8$ per group) were decapitated 30 or 90 min later, and brains were dissected and rapidly frozen to dry ice. Trunk blood was collected into heparinized tubes and centrifuged. Brain tissues and plasma were stored at $-20^{\circ} \mathrm{C}$ until assayed. Before analyses, brains were homogenized mechanically (Ultra-Turrax; Janke \& Kunkel GmbH, Staufen, Germany) in 0.1 M perchloric acid (Merck, Darmstadt, Germany) and added up to a total of $4 \mathrm{gm}$. Morphine in rat plasma and brain were determined by an HPLC method using an electrochemical detection (Zharkovsky et al., 1999).

Statistical analyses. Statistical analysis was conducted using SAS-STAT software (release 6.11; SAS Institute, Cary, NC). Analysis of the descriptive statistics procedure by the SAS-STAT Univariate procedure demonstrated that some of the data were not distributed normally (WilksShapiro's test). The distribution-free three-factorial ANOVA was conducted using a combination of the rank and general linear model (GLM) procedures. Repeated-measures design was applied when necessary. Briefly, data were ranked, and the ranks were later subjected to ANOVA (GLM procedure for unbalanced design with unequal group 

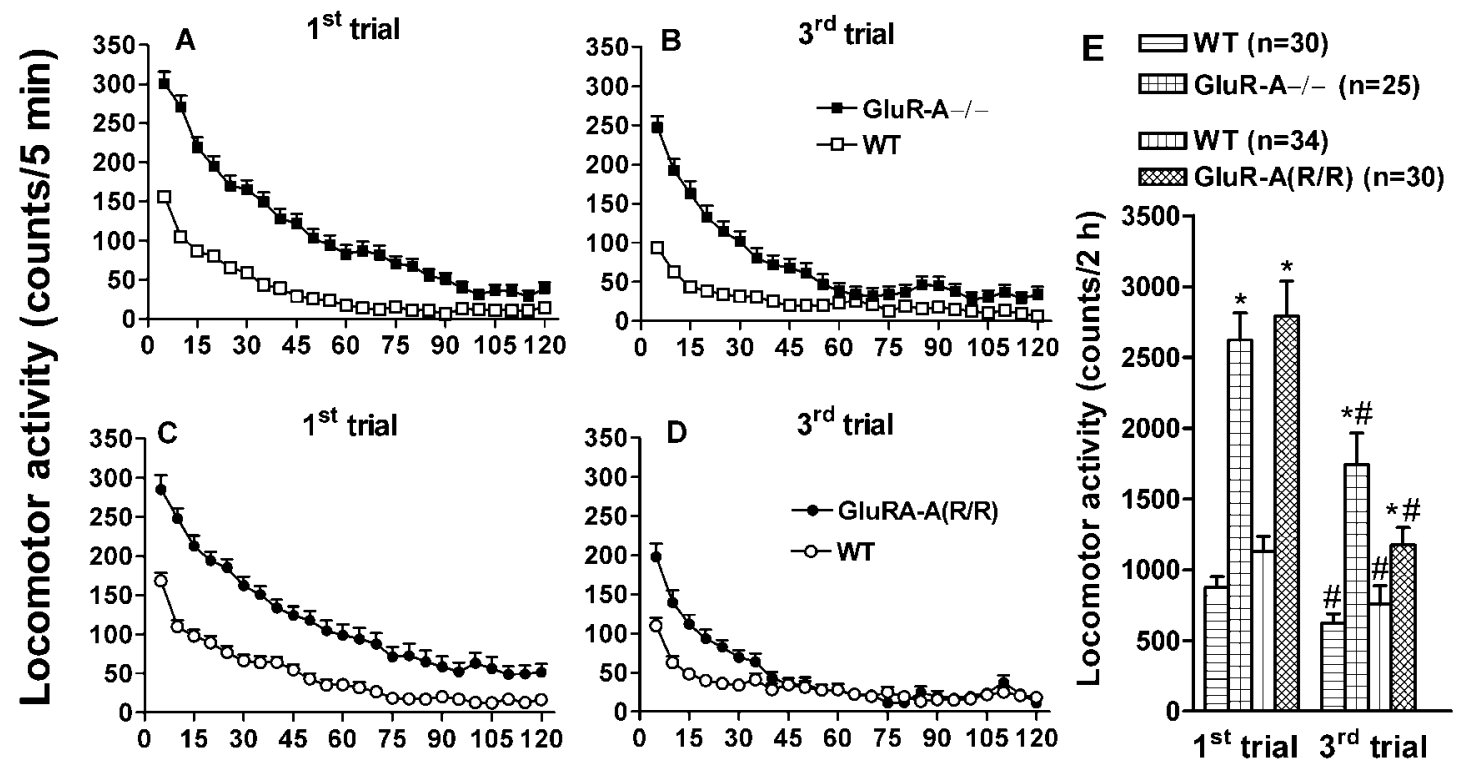

Time (min)

Figure 2. Spontaneous horizontal locomotor activity in a novel cage (first trial, $A$ and $C$ ) and habituation to repeated exposures (third trial, $B$ and $D$ ) to the same environment in drug and handling naïve GluR-A subunit-deficient mouse lines and their wild-type controls. The mouse line codes (with the number of animals) are shown. Both mutant lines had higher activity than the wild-type controls, which can be seen in $E$, depicting the total activity scores. Repeated trials demonstrated that all of the lines habituated to the test environment, but still on the third trial the mutants exhibited higher activity than their controls. Points and bars indicate means \pm SEM. ${ }^{*} p<0.05$ for the difference from the corresponding activity of the control line; \# $p<$ 0.05 for the difference between the trials within a line; Duncan's test.

size). For conditioned sensitization experiment, the factors were as follows: 1, strain (knock-outs or their wild-type littermates); 2 , treatment (levels of paired, unpaired, or control); and 3, test day (test 1 or test 2, test 1 or test 3 ). For tolerance and dependence experiment, the factors were as follows: 1 , strain; 2 , treatment (morphine or saline); and 3, test day (before the chronic administration or after it). For analysis of acute locomotor effect by various drugs, two-factorial analyses were used, with the following factors: 1, strain; and 2, dose. Duncan's or Dunnett's tests were conducted for post hoc analyses of between-group comparisons (only when ANOVA revealed significant main effects). Null hypothesis was rejected at the $p<0.05$ level.

\section{RESULTS}

GluR-A subunit-deficient mice have increased locomotor activity in a novel environment

In agreement with Zamanillo et al. (1999), GluR-A-/- mice were slightly hyperactive when placed in a novel environment of locomotor cages compared with their littermate, wild-type controls $\left(F_{(1,79)}=53 ; p<0.0001\right)$ (Fig. 2). When the measurement was repeated daily, both knock-out and wild-type mice showed clear habituation, but a slight difference in ambulation still prevailed. The mice with genetically impaired GluR-A subunits (R/R mutants) were also slightly hyperactive compared with their littermates $\left(F_{(1,64)}=25 ; p<0.0001\right)$ (Fig. 2), and, also in these mice, habituation to repeated exposure to novel cages was detected.

In both line pairs, the locomotor activity difference was present in both sexes [the gender factor was not significant for the locomotor activity counts: GluR-A-/- mutants and their littermates, $F_{(1,79)}=0.38$, NS; GluR-A(R/R) mutants and their littermates, $F_{(1,64)}=2.2$, NS]. In all following experiments, except for using only males in the determination of morphine pharmacokinetics and the effects of MK-801 (see below), approximately equal number of males and females were used. No significant gender effects were detected in any of the experiments (statistics not shown).

\section{Morphine-induced locomotor activity is slightly enhanced in GluR-A-/- mice}

Acute injection of morphine dose dependently increased locomotor activity in habituated animals of all mouse lines (GluR-A - /and controls, $F_{(3,120)}=35, p<0.0001$; GluR-A(R/R) mutants and controls, $\left.F_{(3,64)}=78, p<0.0001\right)$ (Fig. 3). The responses of GluR-A $-/-$ mice to morphine $\left(F_{(3,120)}=15 ; p<0.001\right)$, but not those of GluR-A(R/R) mutants $\left(F_{(3,64)}=1.2 ; p>0.05\right)$, were significantly bigger than those of the wild type. However, the baseline values of the GluR-A-/- mice were higher than those of their controls (Dunnett's test; $p<0.05$ ), and no interaction between the line and treatment factors was found $\left(F_{(3,120)}=1.35\right.$; $p>0.05)$.

\section{Reduced morphine tolerance and withdrawal in GluR-A-I- mice}

To test the development of morphine tolerance, the mice were first tested for the antinociceptive action of $5 \mathrm{mg} / \mathrm{kg}$ morphine using the tail-flick latency test, a reproducible and robust test for morphine efficacy that has been demonstrated to be affected by AMPA receptor antagonists in chronic studies (Kest et al., 1997). The baseline latencies were similar in all mouse lines (Fig. 4A), except for slightly longer latencies of the GluR-A-/- mice in the first trial. The test dose of morphine was antinociceptive in all animals. Repeated treatment with escalating doses of morphine produced significant tolerance to the antinociceptive effect of morphine in all mouse lines, except for the GluR-A-/ - mice, in which morphine still produced a clear antinociception $\left(F_{(1,84)}=\right.$ 4.17, $p<0.05$ and $F_{(1,84)}=4.15, p<0.05$ for the interaction 


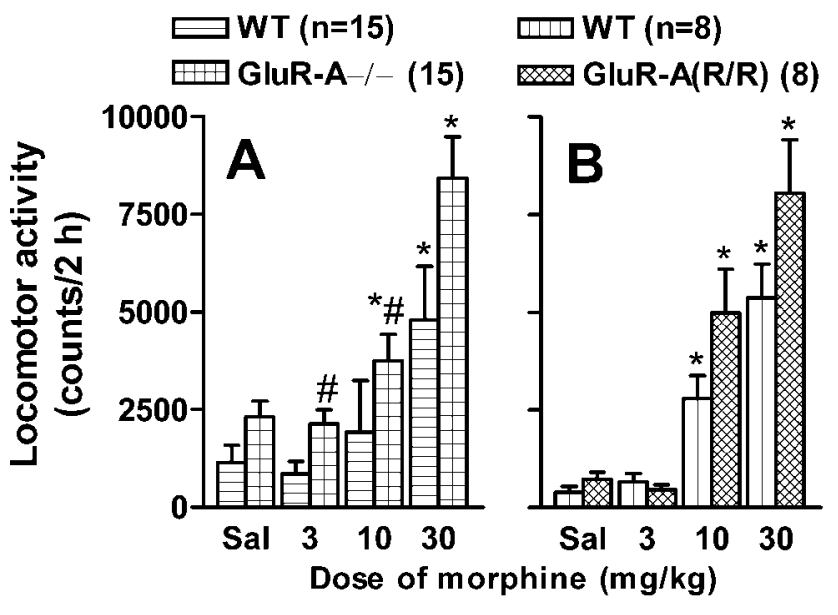

Figure 3. Dose dependency of acute subcutaneous morphine injection on horizontal locomotor activity of GluR-A-/ - and wild-type control mice $(A)$ and on that of GluR-A(R/R) and wild-type control mice $(B)$. Number of animals is given in the figure, in which the bars indicate means \pm SEM for total activities for $2 \mathrm{hr}$. All measurements were performed after three habituation trials. ${ }^{*} p<0.05$ for the difference from the corresponding saline-treated ( $\mathrm{Sal}$ ) group; Dunnett's test. $\# p<0.05$ for the difference from the value for the corresponding control line; Duncan's test.

between GluR-A-/- and control mice and drug treatment at 30 and 60 min tests, respectively) (Fig. 4B,C).

Thereafter, the same animals received naloxone $(0.4 \mathrm{mg} / \mathrm{kg})$ to precipitate opioid withdrawal symptoms, which were scored for their severity and frequency. In saline-treated animals, naloxone did not induce any symptoms. All morphine-treated animals showed some signs of withdrawal (Fig. $5 A$ ), but in GluR-A-/mice, the total scores were significantly lower than in wild-type littermates $\left(F_{(1,22)}=6.13 ; p<0.05\right)$. There was no difference between the GluR-A(R/R) mutants and their wild types $\left(F_{(1,24)}\right.$ $=0.63$; NS). In another dependence experiment using slightly different morphine and naloxone doses, ANOVA detected an interaction between the treatment (saline vs morphine) and mouse line (GluR-A-/- mice vs littermates) in the withdrawal scores $\left(F_{(1,27)}=6.08 ; p<0.05\right)$. The GluR-A-/ - mice had a lower number of naloxone-precipitated symptoms than their littermates after chronic morphine, but not after saline, treatment (Fig. $5 B$ ). The withdrawal scores for mutants and wild types were higher in this second experiment than in the first one (Fig. $5 A$ ), but they were less severe because no weight loss or diarrhea were detected in any of the mice.

The blood and brain concentrations of morphine were determined with HPLC in GluR-A-/- mice and wild-type littermates after a single morphine injection $(10 \mathrm{mg} / \mathrm{kg}$, s.c.). There were no differences in the morphine levels in brain and blood plasma samples $\left(F_{(1,29)}<2.1\right.$, NS) between the genotypes, suggesting similar absorption and elimination of brain morphine (Table 1). This indicates that the differential behavioral responses to morphine were attributable to factors other than pharmacokinetic ones.

\section{Context-dependent sensitization to morphine is retained in the GluR-A subunit-deficient mice}

To find out whether the environment in which the repeated treatment with a moderate dose of morphine was performed affected the responses of the mouse lines, we first tested all mice with a low dose of morphine $(3 \mathrm{mg} / \mathrm{kg}$, s.c.). Then they received five daily injections of morphine $(10 \mathrm{mg} / \mathrm{kg})$ in either the home (unpaired) or locomotor activity (paired) cages, before being retested with $3 \mathrm{mg} / \mathrm{kg}$ morphine. A saline control group was also included. The alterations in ambulatory activity at the retest (test 1 vs test 2) was dependent on mouse line (GluR-A-/- mutants and their controls, $F_{(1,158)}=6.76, p<0.05$; GluR-A(R/R) mutants and their controls, $\left.F_{(1,128)}=4.23, p<0.05\right)$ and the treatment group (GluR-A-/- mutants and their controls, $F_{(2,158)}$ $=4.36, p<0.05$; GluR-A(R/R) mutants and their controls, $\left.F_{(2,128)}=5.31, p<0.01\right)$. The results show that, in the GluR$\mathrm{A}-/-$ and GluR-A(R/R) mutants, morphine-induced sensitization took place effectively only in the $\mathrm{P}$ group, which had repeated morphine injections in the same environment as the final testing was performed (Fig. 6). These effects became clearer $5 \mathrm{~d}$ after the repeated dosing (Fig. 6, Test3). The littermate controls showed increased activity in response to morphine injection independent of the environment of repeated morphine injections when compared with the corresponding saline group. There was a small, but significant sensitization to morphine test dose in the unpaired control groups only when both wild-type groups were combined $(p<0.05$ between test 1 and test 3$)$.

\section{Context-dependent sensitization to D-amphetamine is enhanced in GluR-A-/- mice}

To test whether stimulants affect differently the locomotor activity in GluR-A-/ - mice and their littermates, we used repeated administration of D-amphetamine in context-dependent and context-independent conditions. ANOVA indicated significant mouse line $\left(F_{(1,790)}=6.81 ; p<0.05\right)$ and treatment $\left(F_{(3,79)}=\right.$ 12.21; $p<0.05$ ) effects (Fig. 7), with D-amphetamine inducing a greater environment-dependent sensitization of locomotor activity in GluR-A $-/-$ mice than in wild-type littermates $(p<0.05)$. No significant D-amphetamine-induced context-independent sensitization was observed in the GluR-A-/- or littermate controls. A tendency for increased context-dependent sensitization was also observed in the GluR-A(R/R) mutants (tested only in the paired protocol; data not shown), because the increase in amphetamine-induced activity after repeated amphetamine administration was significant only in the GluR-A(R/R) mutants $(p<0.05)$. These results suggest that the GluR-A mutant mice display strong context-dependent sensitization to stimulants, as they do to morphine.

NMDA receptor-uncompetitive blockers induce a high locomotor activity (Ginski and Witkin, 1994; Velardo et al., 1998; Sukhotina et al., 1999). We wanted to find out whether the specific NMDA receptor-uncompetitive antagonist MK-801 affects differentially the mutant mouse lines and their control lines. However, the dose-dependent increase of ambulatory activity by MK-801 was similar in both line pairs (drug effects: GluR-A-/male mice and their wild types, $F_{(4,75)}=21, p<0.001$; GluR$\mathrm{A}(\mathrm{R} / \mathrm{R})$ male mice and their wild types, $F_{(4,63)}=35, p<0.0001$; line effects: GluR-A $-/-$ male mice and their wild types, $F_{(1,75)}=$ 2.93, NS; GluR-A(R/R) male mice and their wild types, $F_{(1,63)}=$ 0.75 , NS) (Fig. 8), suggesting that the NMDA receptor activity is not altered in GluR-A mutant mice.

\section{DISCUSSION}

The actions of and adaptation to drugs of abuse are complex neurobiological processes that have key neurochemical components. The present findings clarify the role of one suggested molecular factor, the GluR-A subunit of the AMPA-type glutamate receptors in morphine-dependent behaviors. Our results 

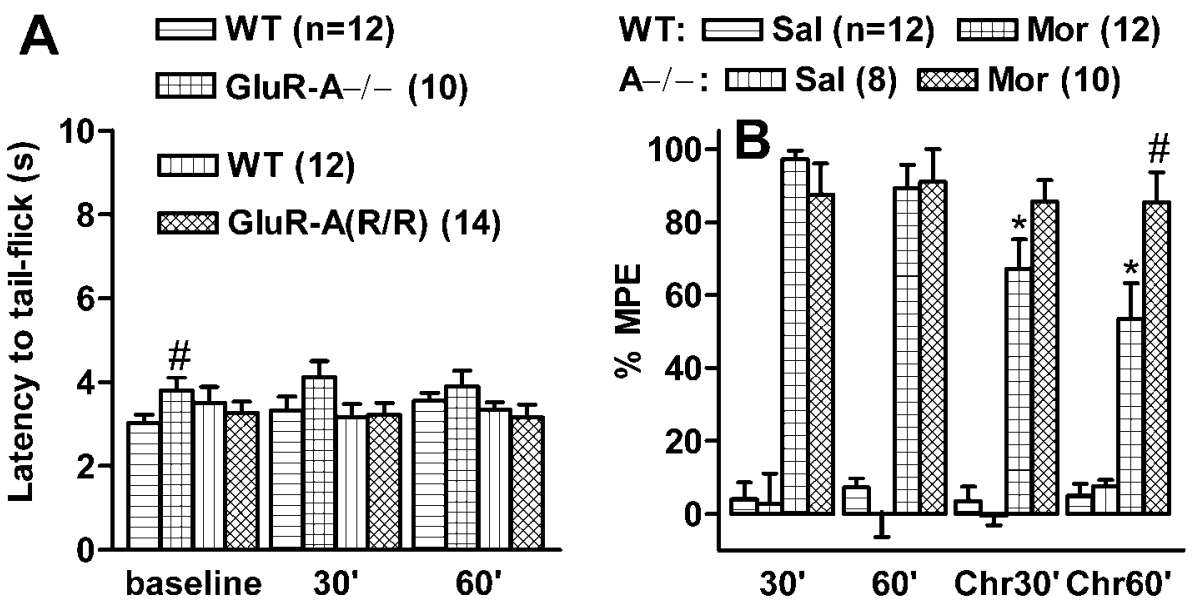

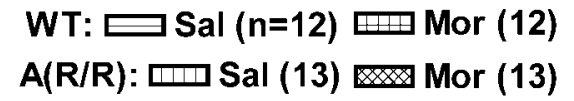

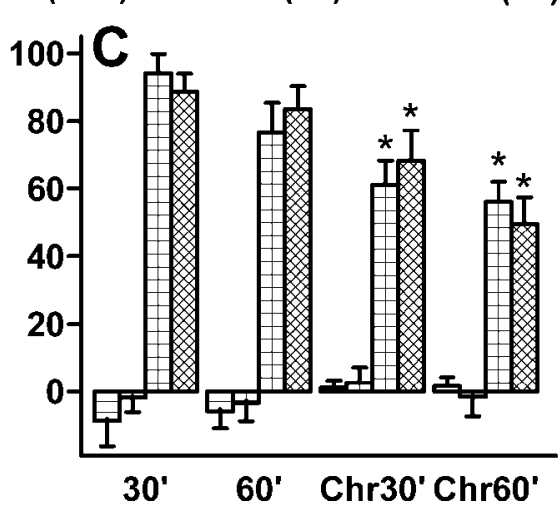

Figure 4. Tail-flick latencies in GluR-A subunit-deficient mouse lines and their wild-type controls in drug-free $(A)$ and morphine-affected states $(B, C)$. $A$, Tail-flick latencies of the initial baseline trial and the trials 30 and $60 \mathrm{~min}$ after the injection of saline $(\mathrm{Sal} ; 10 \mathrm{ml} / \mathrm{kg}, \mathrm{s.c}$.). $B, C, \mathrm{Percentage}$ of the maximal possible effect (\%MPE) at 30 and $60 \mathrm{~min}$ after saline or morphine (Mor; $5 \mathrm{mg} / \mathrm{kg}$ ) injections in GluR-A-/- and wild-type control mice (B) and in GluR-A(R/R) and their control mice $(C)$ before the chronic treatment and $15 \mathrm{hr}$ after the last injection of $8 \mathrm{~d}$ of chronic morphine treatment with escalating doses $(\mathrm{Chr})$. The bars indicate means \pm SEM. ${ }^{*} p<0.05$ for the difference from the corresponding acute morphine value; $\# p<0.05$ for the difference from the corresponding control mouse line; Duncan's test.
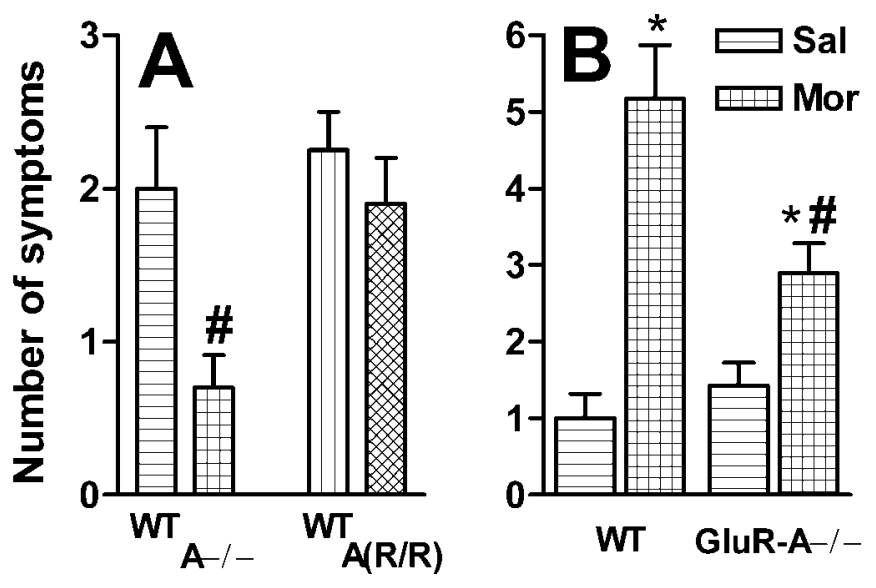

Figure 5. Naloxone-precipitated withdrawal symptoms after chronic morphine administration. $A$, GluR-A-/- and GluR-A(R/R) mutant mice and their wild-type controls were treated with escalating morphine doses for $9 \mathrm{~d}$, and withdrawal symptoms were precipitated $24 \mathrm{hr}$ after the last injection by $0.4 \mathrm{mg} / \mathrm{kg}$ naloxone. The bars indicate mean \pm SEM withdrawal scores $(n=11-12)$ summed from the number of appearance of the following symptoms within $15 \mathrm{~min}$ of the naloxone injection: forepaw tremor, head twitch, writhe, diarrhea, lying, and forepaw treading. $\# p<0.05$ for the difference from the corresponding control mouse line; Duncan's test. Naloxone at this dose after saline treatment failed to induce any of these symptoms in any of the mouse lines (data not shown). $B$, GluR-A-/- mice and their wild-type controls were treated with escalating morphine (Mor) doses for $6 \mathrm{~d}$, and withdrawal symptoms were precipitated $2 \mathrm{hr}$ after the last injection by $1.0 \mathrm{mg} / \mathrm{kg}$ naloxone. Saline controls $(\mathrm{Sal})$ were treated similarly. The bars indicate mean \pm SEM withdrawal scores $(n=5-9)$ summed from the number of appearance of the following symptoms within 25 min of the naloxone injection: jumps, digging, forepaw tremor, head twitch, writhe, and lying. ${ }^{*} p<0.05$ for the difference from the corresponding saline value; Dunnett's test. $\# p<0.05$ for the difference from the corresponding control mouse line; Duncan's test.

confirm the previous suggestions that GluR-A subunits are operative in the process of sensitization to morphine (Fitzgerald et al., 1996; Carlezon et al., 1997; Lu et al., 1997; Churchill et al., 1999; Lu and Wolf, 1999) and extend those results by indicating that the
Table 1. Mean \pm SEM concentrations of morphine in plasma $(\mathrm{ng} / \mathrm{ml})$ and brain (ng/gm) of GluR-A-/- mice and their wild-type (WT) controls 30 and $90 \mathrm{~min}$ after subcutaneous injection of $10 \mathrm{mg} / \mathrm{kg}$ morphine $(n=7-8)$

\begin{tabular}{lll} 
Sample & $30 \mathrm{~min}$ & $90 \mathrm{~min}$ \\
\hline Plasma & & \\
WT & $995 \pm 243$ & $255 \pm 23$ \\
GluR-A-/- & $768 \pm 112$ & $191 \pm 61$ \\
Brain & & \\
WT & $169 \pm 12$ & $125 \pm 6$ \\
GluR-A-/- & $196 \pm 16$ & $134 \pm 14$
\end{tabular}

$\overline{\text { No statistically significant differences between the mouse lines; Duncan's test; } p>}$ 0.05 .

context-dependent sensitization is not eliminated by the loss of those subunits, whereas the context-independent sensitization is. Considering that context-dependent sensitization may resemble a learning process, our results are in agreement with the normal learning ability of these mice in spatial tasks (Zamanillo et al., 1999) and with their normal habituation during repeated locomotor activity (the present study). They also signify that environmental factors have a strong influence on the effects of drugs of abuse via molecular mechanisms and brain pathways that are different from those operative in the direct drug actions. The GluR-A subunit-deficient mice exhibited at least as high locomotor responses to acute morphine administration as their littermates but had reduced development of tolerance and reduced emergence of withdrawal symptoms. This suggests that GluR-A subunit-expressing neurons, perhaps the interneurons known to express GluR-A but not GluR-B subunits (Geiger et al., 1995), are involved in neurochemical pathways normally affected by morphine.

The higher baseline locomotor activity of the GluR-A-/mice is a confounding factor in the present study with regard to the sensitization phenomenon. However, for the interpretation of the present results, this factor is not essential, because we had another mouse line with impaired GluR-A subunit-mediated synaptic transmission. The GluR-A subunits were engineered to 
Saline Unpaired morphine Paired morphine

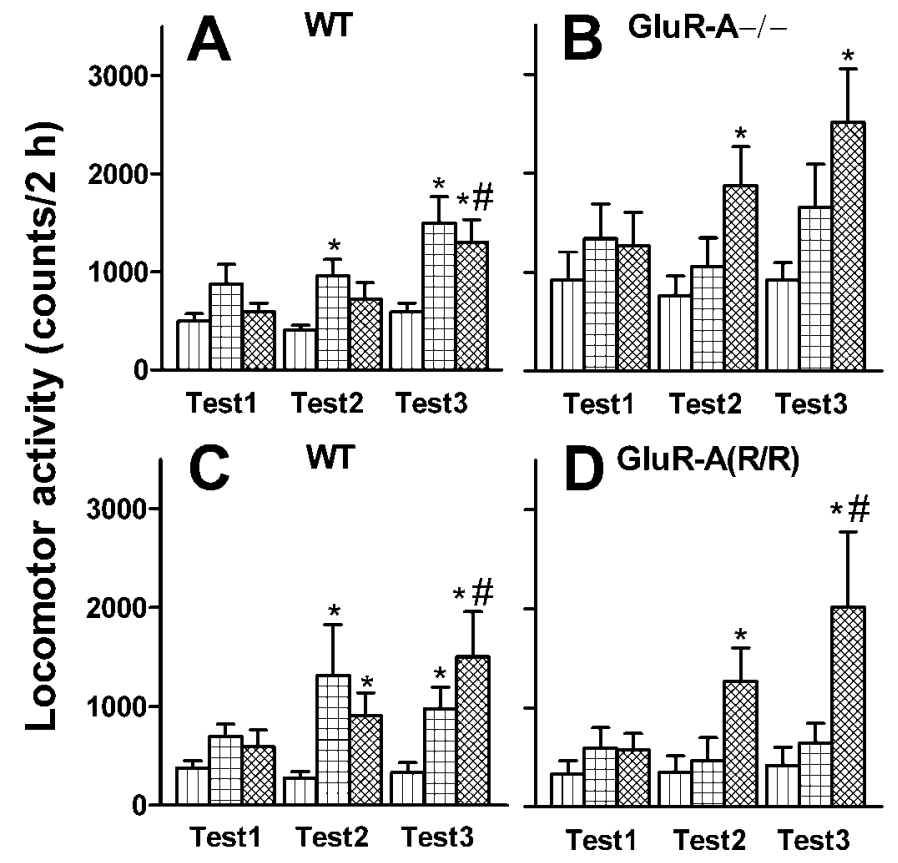

Figure 6. Effects of $6 \mathrm{~d}$ repeated morphine $(10 \mathrm{mg} / \mathrm{kg}$, s.c. $)$ treatment on horizontal locomotor activity of GluR-A-/- $(B)$ and GluR-A(R/R) $(D)$ mutant mice and their wild-type controls $(A, C$, respectively). The bars indicate means \pm SEM $(n=10-14)$ for ambulatory activity counts after a morphine test dose of $3 \mathrm{mg} / \mathrm{kg}$ (subcutaneous), which normally induces no clear locomotor stimulation. The tests were performed first with naïve but habituated animals (Test 1 ), then $24 \mathrm{hr}$ (Test2), and then $5 \mathrm{~d}$ after the last morphine dose (Test3). In each mouse line, the treatment groups consisted of the control saline-treated group (injected twice per day with saline, once in home cages and once in locomotor activity cages), the unpaired morphine group (saline in activity cages and morphine in home cages), and the paired morphine group (morphine in activity cages and saline in home cages). ${ }^{*} p<0.05$ for the difference from the corresponding saline control group; \#p $<0.05$ for the difference from the corresponding activity counts in test 1 ; Dunnett's test.

express an arginine in their channel-forming loops critical for ion selectivity, strongly reducing the calcium permeability and singlechannel conductance in the same way as in RNA-edited, argininecontaining GluR-B subunits (Burnashev et al., 1992; Swanson et al., 1997). Because GluR-A subunits are strongly expressed in most interneurons with low GluR-B subunit expression (Geiger et al., 1995), the GluR-A(R/R) mutants are expected to have a major change in the cation selectivity of their AMPA responses in the interneurons, because the mutant receptors are $\mathrm{Ca}^{2+}$ impermeable. The GluR-A(R/R) mice, demonstrated to express the GluR-A(R) protein in their brains (Fig. $1 D$ ), had only slightly elevated locomotor activities at baseline but still showed elevated responses to morphine selectively in the specific environmental context. Furthermore, because these mice entirely lacked sensitization when the treatment was repeated in home cages, the data suggest that the wild-type GluR-A subunit-containing receptors are needed for morphine sensitization in the absence of specific environmental cues but not when environmental cues are present. This is in line with the demonstration that viral vector-mediated overexpression of GluR-A subunits in the rat brain (Carlezon et al., 1997) without environmental cueing sensitizes the locomotor responses of the animals to morphine.

Although the NMDA receptors have been implicated in the

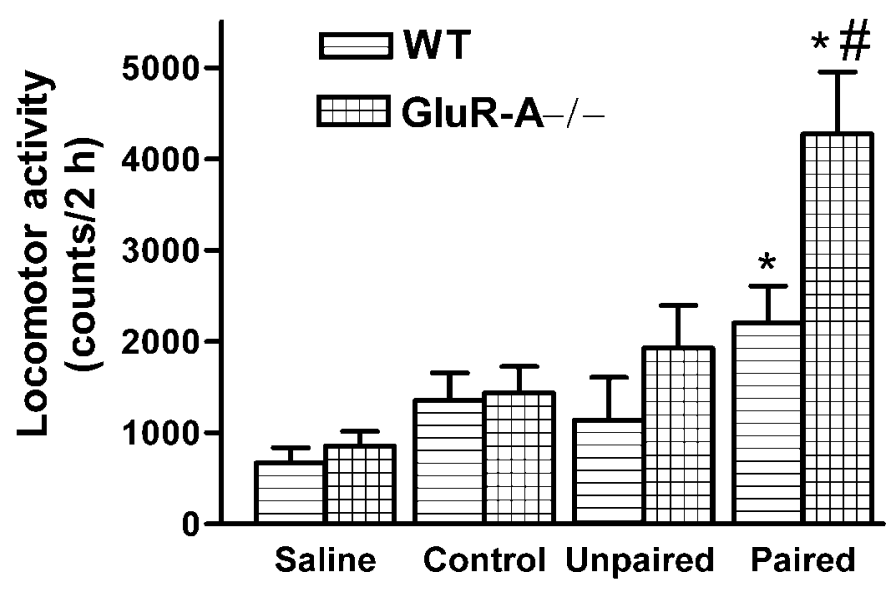

Figure 7. The effect of repeated D-amphetamine administration on amphetamine-induced locomotor activity of GluR-A-/- mutant mice and their wild-type (WT) controls. The mice were injected with $2 \mathrm{mg} / \mathrm{kg}$ (subcutaneous) amphetamine or $10 \mathrm{ml} / \mathrm{kg}$ saline for $5 \mathrm{~d}$ in either locomotor activity cages (Paired) or home cages (Unpaired). After $5 \mathrm{~d}$, immediately before being transferred into locomotor activity cages, the salinetreated animals received either saline injection (Saline) or $0.5 \mathrm{mg} / \mathrm{kg}$ amphetamine (Control), and the amphetamine-treated animals received $0.5 \mathrm{mg} / \mathrm{kg}$ amphetamine. The bars indicate mean \pm SEM $(n=12-16)$ horizontal activity counts for $2 \mathrm{hr}$ sessions. ${ }^{*} p<0.05$ for the difference from the corresponding saline and control group; $\# p<0.05$ for the difference from the corresponding control mouse line; Duncan's test.

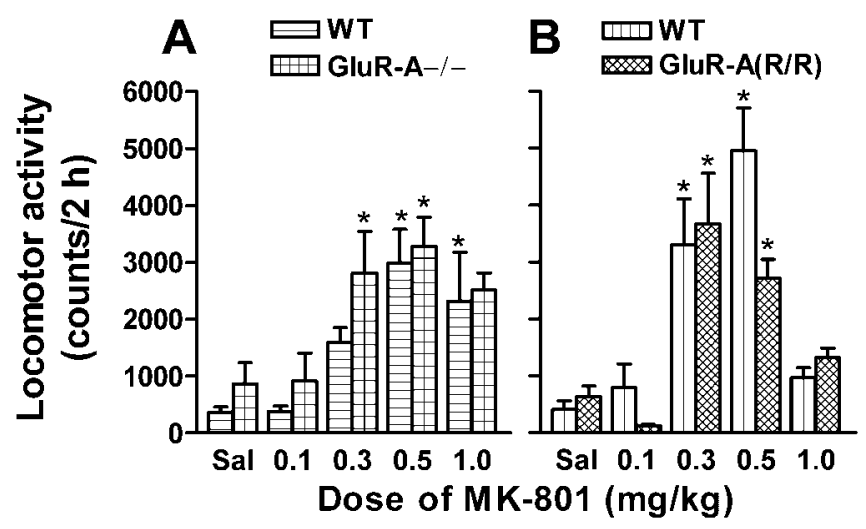

Figure 8. The effect of acute NMDA receptor blockade by MK-801 on locomotor activity of GluR-A-/ - and GluR-A(R/R) mutant mice and their wild-type controls. The mice received either saline $(10 \mathrm{ml} / \mathrm{kg}$, i.p.) or different doses of MK-801, after which they were immediately transferred into locomotor cages for the determination of horizontal activity counts for $2 \mathrm{hr}$ sessions. The bars indicate mean \pm SEM for 11-20 animals in GluR-A-/- and control groups and for 10-13 animals in GluR$\mathrm{A}(\mathrm{R} / \mathrm{R})$ and their control groups. ${ }^{*} p<0.05$ for the difference from the corresponding saline group; Dunnett's test. There were no significant differences between the mutants and their controls.

development of tolerance to morphine, we failed to see any clear differences in the locomotor actions of NMDA receptor blockade by MK- 801 between the mutant and their respective control lines. As far as MK-801-induced locomotor activity is caused by blockade of basal function of the NMDA receptors, our results suggest normal functioning of the NMDA component of the glutamate system in GluR-A - / - mice and fail to explain the diminution of morphine tolerance by reduced NMDA receptor functioning. Because in our study the tolerance and dependence to morphine were lower in the absence of GluR-A subunits, but not when only AMPA receptor functionality was compromised [GluR-A(R/R) 
mutants], it is likely that the mutant GluR-A(R) subunit can normally mediate the AMPA-receptor adaptation under chronic morphine, e.g., by increased membrane targeting. Whatever the mechanism, this adaptation to chronic morphine is apparently not coupled to GluR-A subunit-containing AMPA receptormediated $\mathrm{Ca}^{2+}$ conductance in the interneurons. It could involve enhanced excitability of these neurons because of a putative increase in GluR-A subunit-containing AMPA receptor channels (Fitzgerald et al., 1996; Carlezon et al., 1997; Lu et al., 1997; Churchill et al., 1999; Lu and Wolf, 1999), the process of which is deficient in GluR-A-/- mice.

There is recent evidence for potentiation of $\mu$-opioid agonistinduced analgesia by AMPA receptor antagonists (Nishiyama et al., 1998) and for an interaction between $\mu$-opioid and AMPA receptor responses studied electrophysiologically in isolated spinal dorsal horn neurons (Kolaj and Randic, 1996). It is thus likely that these effects were deficient in GluR-A-/- animals when tolerance to morphine was assayed by the tail-flick test, although acute morphine produced similar antinociception in the knockouts and their littermates. Detailed molecular events remain unknown, and it is not clear whether mechanisms regulating pathways important for morphine-induced hyperlocomotion are homologous to the spinal dorsal horn nociceptive pathways and pathways defining various withdrawal symptoms. However, it is known that both $\mu$-opioid receptors and GluR-A subunits are expressed widely in the forebrain regions (Sato et al., 1993; Mansour et al., 1994), including the nucleus accumbens that is implicated in locomotor stimulation by various drugs of abuse. There is no evidence for direct molecular interaction between $\mu$-opioid and AMPA receptors, and therefore, we think that the AMPA receptor-containing neurons may be targets of neuronaldepressing action of morphine, to which these neurons then adapt by changes in AMPA receptors upon repeated morphine administration. The present animal model fails to assess the significance of AMPA receptors in any given brain region for morphine effects, because the expression of GluR-A subunit mutations was under native promoters. Actually, the slight acute enhancement of morphine effects in the GluR-A-/- animals might be better explained by reduced AMPA responses in the nucleus accumbens than the ventral tegmental area. This would be consistent with the results of Kelz et al. (1999) who showed that an increased level of GluR-A subunit in the nucleus accumbens is associated with aversion to cocaine-paired environment.

There are presently no AMPA receptor subtype-selective antagonists, and therefore, it is difficult to assess whether our findings are attributable to direct inactivation or malfunction of GluR-A subunit-containing AMPA receptors or to indirect alterations in neuronal circuitry caused by the primary receptor alteration. It should be also noted that the findings of the present study may be partly affected by the possible alterations in neuronal development in GluR-A subunit-deficient mice, because these subunits are expressed early in the brain development (Monyer et al., 1991). However, several nonselective AMPA antagonists have been studied and found to affect the development and expression of behavioral sensitization to stimulants and opioids in various rat and mouse models (Burns et al., 1994; Li et al., 1997; McLemore et al., 1997; Mead and Stephens, 1998; Carlezon et al., 1999). These results have established the involvement of the AMPA receptors in behavioral sensitization and, therefore, our present results on a new animal model are consistent with the previous pharmacological studies. Additional studies are warranted to dissect out the role of GluR-A subunit-containing AMPA receptors in the acquisition and expression of primary rewarding effects and other conditioned activity. The existence of context-dependent sensitization of the GluR-A subunit-deficient mouse lines was not restricted to opioids but could be observed also with amphetamine, and with this stimulant, the sensitization was actually enhanced in GluR-A mutants compared with the wild types. However, the same protocol with unpaired amphetamine administration schedule failed to induce any sensitization in the wildtype (or GluR-A-/-) animals, preventing any conclusion on the mechanisms of context-independent sensitization to stimulants. Enhanced context-dependent sensitization to stimulants indicates a wider role for AMPA receptors in adaptation to the effects of drugs of abuse, in keeping with the proposition that the loss of AMPA receptors in the ventral striatum, the main site of stimulant action, should enhance context-dependent effects of stimulants (Kelz et al., 1999).

The AMPA receptors are known to be rapidly regulated in neuronal membranes (Turrigiano, 2000) during neuronal activity and, therefore, they would seem to be suitable substrates for neuronal plasticity and learning and memory. Our results support the role of GluR-A subunit-containing receptors in plasticity associated with the development of tolerance and dependence but not in the development and/or expression of context dependency of morphine-induced locomotor stimulation. The $\mathrm{Ca}^{2+}$ dependent processes, especially in GluR-B subunit-deficient interneurons, are apparently only required for some of the morphine-induced adaptations.

\section{REFERENCES}

Bardo MT (1998) Neuropharmacological mechanisms of drug reward: beyond dopamine in the nucleus accumbens. Crit Rev Neurobiol 12:37-67.

Belozertseva I, Zvartau E, Bespalov A (1996) Behavioral effects of MK801 in morphine-dependent and non-dependent mice. Life Sci 58:L55-L61.

Berke JD, Hyman SE (2000) Addiction, dopamine, and the molecular mechanisms of memory. Neuron 25:515-532.

Brusa R, Zimmermann F, Koh DS, Feldmeyer D, Gass P, Seeburg PH, Sprengel R (1995) Early-onset epilepsy and postnatal lethality associated with an editing-deficient GluR-B allele in mice. Science 270:1677-1680.

Burnashev N, Monyer H, Seeburg PH, Sakmann B (1992) Divalent ion permeability of AMPA receptor channels is dominated by the edited form of a single subunit. Neuron 8:189-198.

Burns LH, Everitt BJ, Kelley AE, Robbins TW (1994) Glutamatedopamine interactions in the ventral striatum: role in locomotor activity and responding with conditioned reinforcement. Psychopharmacology (Berl) 115:516-528.

Carlezon Jr WA, Boundy VA, Haile CN, Lane SB, Kalb RG, Neve RL, Nestler EJ (1997) Sensitization to morphine induced by viralmediated gene transfer. Science 277:812-814.

Carlezon Jr WA, Rasmussen K, Nestler EJ (1999) AMPA antagonist LY293558 blocks the development, without blocking the expression, of behavioral sensitization to morphine. Synapse 31:256-262.

Churchill L, Swanson CJ, Urbina M, Kalivas PW (1999) Repeated cocaine alters glutamate receptor subunit levels in the nucleus accumbens and ventral tegmental area of rats that develop behavioral sensitization. J Neurochem 72:2397-2403.

Everitt BJ, Parkinson JA, Olmstead MC, Arroyo M, Robledo P, Robbins TW (1999) Associative processes in addiction and reward. The role of amygdala-ventral striatal subsystems. Ann NY Acad Sci 877:412-438.

Fitzgerald LW, Ortiz J, Hamedani AG, Nestler EJ (1996) Drugs of abuse and stress increase the expression of GluR1 and NMDAR1 glutamate receptor subunits in the rat ventral tegmental area: common adaptations among cross-sensitizing agents. J Neurosci 16:274-282.

Geiger JR, Melcher T, Koh DS, Sakmann B, Seeburg PH, Jonas P, Monyer H (1995) Relative abundance of subunit mRNAs determines gating and $\mathrm{Ca}^{2+}$ permeability of AMPA receptors in principal neurons and interneurons in rat CNS. Neuron 15:193-204.

Ginski MJ, Witkin JM (1994) Sensitive and rapid behavioral differentiation of $N$-methyl-D-aspartate receptor antagonists. Psychopharmacology (Berl) 114:573-582.

Gu H, Zou YR, Rajewsky K (1993) Independent control of immuno- 
globulin switch recombination at individual switch regions evidenced through Cre-loxP-mediated gene targeting. Cell 73:1155-1164.

Jang CG, Rockhold RW, Ho IK (2000) An autoradiographic study of $\left[{ }^{3} \mathrm{H}\right]$ AMPA receptor binding and in situ hybridization of AMPA sensitive glutamate receptor A (GluR-A) subunits following morphine withdrawal in the rat brain. Brain Res Bull 52:217-221.

Kelz MB, Chen J, Carlezon Jr WA, Whisler K, Gilden L, Beckmann AM, Steffen C, Zhang YJ, Marotti L, Self DW, Tkatch T, Baranauskas G, Surmeier DJ, Neve RL, Duman RS, Picciotto MR, Nestler EJ (1999) Expression of the transcription factor $\Delta$ FosB in the brain controls sensitivity to cocaine. Nature 401:272-276.

Kest B, McLemore G, Kao B, Inturrisi CE (1997) The competitive alpha-amino-3-hydroxy-5-methylisoxazole-4-propionate receptor antagonist LY293558 attenuates and reverses analgesic tolerance to morphine but not to delta or kappa opioids. J Pharmacol Exp Ther 283:1249-1255.

Kohler M, Kornau HC, Seeburg PH (1994) The organization of the gene for the functionally dominant $\alpha$-amino-3-hydroxy-5-methylisoxazole-4propionic acid receptor subunit GluR-B. J Biol Chem 269:17367-17370.

Kolaj M, Randic M (1996) $\mu$-Opioid receptor-mediated reduction of $\alpha$-amino-3-hydroxy-5-methyl-4-isoxazolepropionic acid-activated current in dorsal horn neurons. Neurosci Lett 204:133-137.

Koob GF, Sanna PP, Bloom FE (1998) Neuroscience of addiction. Neuron 21:467-476.

Leshner AI, Koob GF (1999) Drugs of abuse and the brain. Proc Assoc Am Physicians 111:99-108

Li Y, Vartanian AJ, White FJ, Xue CJ, Wolf ME (1997) Effects of the AMPA receptor antagonist NBQX on the development and expression of behavioral sensitization to cocaine and amphetamine. Psychopharmacology (Berl) 134:266-276.

Lu W, Wolf ME (1999) Repeated amphetamine administration alters AMPA receptor subunit expression in rat nucleus accumbens and medial prefrontal cortex. Synapse 32:119-131.

Lu W, Chen H, Xue CJ, Wolf ME (1997) Repeated amphetamine administration alters the expression of mRNA for AMPA receptor subunits in rat nucleus accumbens and prefrontal cortex. Synapse 26:269-280.

Malin DH, Lake JR, Newlin-Maultsby P, Roberts LK, Lanier JG, Carter VA, Cunningham JS, Wilson OB (1992) Rodent model of nicotine abstinence syndrome. Pharmacol Biochem Behav 43:779-784

Mansour A, Fox CA, Thompson RC, Akil H, Watson SJ (1994) $\mu$-Opioid receptor mRNA expression in the rat CNS: comparison to $\mu$-receptor binding. Brain Res 643:245-265.

Matthes HW, Maldonado R, Simonin F, Valverde O, Slowe S, Kitchen I, Befort K, Dierich A, Le Meur M, Dolle P, Tzavara E, Hanoune J, Roques BP, Kieffer BL (1996) Loss of morphine-induced analgesia, reward effect and withdrawal symptoms in mice lacking the $\mu$-opioidreceptor gene. Nature 383:819-823.

McLemore GL, Kest B, Inturrisi CE (1997) The effects of LY293558, an AMPA receptor antagonist, on acute and chronic morphine dependence. Brain Res 778:120-126.

Mead AN, Stephens DN (1998) AMPA-receptors are involved in the expression of amphetamine-induced behavioural sensitisation, but not in the expression of amphetamine-induced conditioned activity in mice. Neuropharmacology 37:1131-1138.
Merlo Pich E, Chiamulera C, Carboni L (1999) Molecular mechanisms of the positive reinforcing effect of nicotine. Behav Pharmacol 10:587-596.

Monyer H, Seeburg PH, Wisden W (1991) Glutamate-operated channels: developmentally early and mature forms arise by alternative splicing. Neuron 6:799-810.

Nagy A, Rossant J, Nagy R, Abramow-Newerly W, Roder JC (1993) Derivation of completely cell culture-derived mice from early-passage embryonic stem cells. Proc Natl Acad Sci USA 90:8424-8428.

Nestler EJ (2000) Genes and addiction. Nat Genet 26:277-281.

Nishiyama T, Yaksh TL, Weber E (1998) Effects of intrathecal NMDA and non-NMDA antagonists on acute thermal nociception and their interaction with morphine. Anesthesiology 89:715-722.

Robinson TE, Kolb B (1997) Persistent structural modifications in nucleus accumbens and prefrontal cortex neurons produced by previous experience with amphetamine. J Neurosci 17:8491-8497.

Robinson TE, Kolb B (1999) Morphine alters the structure of neurons in the nucleus accumbens and neocortex of rats. Synapse 33:160-162.

Rodriguez de Fonseca F, Navarro M (1998) Role of the limbic system in dependence on drugs. Ann Med 30:397-405.

Sato K, Kiyama H, Tohyama M (1993) The differential expression patterns of messenger RNAs encoding non- $N$-methyl-D-aspartate glutamate receptor subunits (GluR1-4) in the rat brain. Neuroscience $52: 515-539$

Self DW (1998) Neural substrates of drug craving and relapse in drug addiction. Ann Med 30:379-389.

Self DW, Nestler EJ (1998) Relapse to drug-seeking: neural and molecular mechanisms. Drug Alcohol Depend 51:49-60.

Single FN, Rozov A, Burnashev N, Zimmermann F, Hanley DF, Forrest D, Curran T, Jensen V, Hvalby O, Sprengel R, Seeburg PH (2000) Dysfunctions in mice by NMDA receptor point mutations NR1(N598Q) and NR1(N598R). J Neurosci 20:2558-2566.

Sukhotina IA, Dravolina OA, Medvedev IO, Bespalov AY (1999) Effects of calcium channel blockers on behaviors induced by the $N$-methyl-Daspartate receptor antagonist, dizocilpine, in rats. Pharmacol Biochem Behav 63:569-580.

Swanson GT, Kamboj SK, Cull-Candy SG (1997) Single-channel properties of recombinant AMPA receptors depend on RNA editing, splice variation, and subunit composition. J Neurosci 17:58-69.

Turrigiano GG (2000) AMPA receptors unbound: membrane cycling and synaptic plasticity. Neuron 26:5-8.

Velardo MJ, Simpson VJ, Zahniser NR (1998) Differences in NMDA receptor antagonist-induced locomotor activity and $\left[{ }^{3} \mathrm{H}\right] \mathrm{MK}-801$ binding sites in short-sleep and long-sleep mice. Alcohol Clin Exp Res 22:1509-1515.

Zamanillo D, Sprengel R, Hvalby O, Jensen V, Burnashev N, Rozov A, Kaiser KM, Koster HJ, Borchardt T, Worley P, Lubke J, Frotscher M, Kelly PH, Sommer B, Andersen P, Seeburg PH, Sakmann B (1999) Importance of AMPA receptors for hippocampal synaptic plasticity but not for spatial learning. Science 284:1805-1811.

Zharkovsky A, Katajamaki J, Seppala T, Ahtee L (1999) Morphineinduced analgesia in rats withdrawn from concurrent nimodipine and morphine treatment. Pain 79:217-222. 